\title{
Stabilization and Prolonged Reactivity of Aqueous-Phase Ozone with Cyclodextrin
}

\author{
Adam Dettmer ${ }^{1}$, Raymond Ball ${ }^{2}$, Thomas B. Boving ${ }^{3}$, Naima Khan ${ }^{1}$, Tanner Schaub ${ }^{1}$, \\ Nilusha Sudasinghe ${ }^{1}$, Carlos A. Fernandez ${ }^{4}$, and Kenneth C. Carroll ${ }^{*}$
}

Submitted for Review to

Journal of Contaminant Hydrology

August 18, 2016

Revised

November 15, 2016 


\begin{abstract}
Recalcitrant organic groundwater contaminants, such as 1,4-dioxane, may require strong oxidants for complete mineralization. However, their efficacy for in-situ chemical oxidation (ISCO) is limited by oxidant decay and reactivity. Hydroxypropyl- $\beta$ cyclodextrin (HP $\beta C D)$ was examined for its ability to stabilize aqueous phase ozone $\left(\mathrm{O}_{3}\right)$ and prolong oxidation potential through inclusion complex formation. Partial transformation of $\mathrm{HP} \beta C D$ by $\mathrm{O}_{3}$ was observed. However, $\mathrm{HP} \beta \mathrm{CD}$ proved to be sufficiently recalcitrant, because it was only partially degraded in the presence of $\mathrm{O}_{3}$. The formation of a $\mathrm{HP} \beta \mathrm{CD}: \mathrm{O}_{3}$ clathrate complex was observed, which stabilized decay of $\mathrm{O}_{3}$. The presence of $\mathrm{HP} \beta C D$ increased the $\mathrm{O}_{3}$ half-life linearly with increasing $\mathrm{HP} \beta C D: \mathrm{O}_{3}$ molar ratio. The $\mathrm{O}_{3}$ half-life in solutions increased by as much as 40 -fold relative to $\mathrm{HP} \beta C D$-free $\mathrm{O}_{3}$ solutions. Observed $\mathrm{O}_{3}$ release from $\mathrm{HP} \beta C D$ and indigo oxidation confirmed that the formation of the inclusion complex is reversible. This proof-ofconcept study demonstrates that $\mathrm{HP} \beta \mathrm{CD}$ can complex $\mathrm{O}_{3}$ while preserving its reactivity. These results suggest that the use of clathrate stabilizers, such as HP $\beta C D$, can support the development of a facilitated-transport enabled ISCO for the $\mathrm{O}_{3}$ treatment of groundwater contaminated with recalcitrant compounds.
\end{abstract}

Keywords - cyclodextrin; ozone; advanced oxidation; in-situ chemical oxidation; ISCO; groundwater remediation, clathrate 


\section{INTRODUCTION}

Groundwater contamination with recalcitrant, anthropogenic, organic chemicals remains a common and significant risk to human-health and water-resource sustainability. These contaminants may be treated using in-situ chemical oxidation (ISCO), which involves the introduction of oxidants into the subsurface where contaminants are transformed, through oxidation, into benign by-products (e.g., Huling and Pivetz, 2006). However, some organic contaminants (e.g., 1,4-dioxane) may require strong oxidants (i.e., compounds that have a standard redox potential greater than two volts) to be completely mineralized (Huling and Pivetz, 2006). Such contaminants are currently remediated using ex situ chemical oxidation (Zenker et al., 2003). This does require extraction of contaminated groundwater to the surface before treatment, which is generally inefficient and costly. Although advanced oxidation would be the preferred ISCO remediation method for recalcitrant contaminants, there are significant limitations in the use of strong oxidants for in-situ treatment.

Because of its relatively high standard oxidation potential $(2.07 \mathrm{~V})$, ozone $\left(\mathrm{O}_{3}\right)$ is a proven ISCO reagent for contaminated soil and groundwater (Bhuyan and Latin, 2012; Clayton et al., 2011; Huling and Pivetz, 2006). However, a key limitation for implementation of $\mathrm{O}_{3}$, and other strong oxidants, in the treatment of recalcitrant contaminant is the short half-live and high reactivity of the oxidant in the subsurface environment (Huling and Pivetz, 2006). Radical scavengers, such as transition metals and soil organic matter associated with the subsurface materials, both aqueous and solid, can 
impose a significant oxidant demand, which ultimately reduces the amount of oxidant available for reaction with contaminants and increases the cost of treatment (e.g., Brusseau et al., 2011; Crimi and Siegrist, 2003; Marble et al., 2010; Mumford et al., 2004; Urynowicz, 2008; Xu and Thomson, 2009). The oxidant demand, as well as the reactivity of the oxidants, provides a serious challenge for the development of ISCO in general, and the variability and potential controls of $\mathrm{O}_{3}$ oxidant demand in ISCO systems remains subject to research (e.g., Clayton et al., 2011; Huling and Pivetz, 2006; Lim et al., 2002; Masten, 1991; Masten and Davies, 1997; Wang et al., 2012).

$\mathrm{O}_{3}$ is only sparingly soluble $(\sim 208 \mu \mathrm{M}$ or $10 \mathrm{mg} / \mathrm{L})$ in typical groundwater systems, and for that reason has mainly been injected as a gas (Masten and Davies, 1997). The half-life for aqueous $\mathrm{O}_{3}$ is typically $<1$ hour due to the reactivity of the hydroxyl radical $(\mathrm{OH} \bullet)$. This severely limits $\mathrm{O}_{3}$ delivery to contaminants residing at significant distances away from the oxidant injection point. $\mathrm{O}_{3}$ transforms contaminants through either direct oxidation or through decomposition and production of hydroxyl radicals, which then react with contaminants. Clayton et al. review the relatively selective direct $\mathrm{O}_{3}$ :contaminant reaction mechanisms and indirect contaminant oxidation by radicals generated by $\mathrm{O}_{3}$ (Clayton et al., 2011). The reactions that produce radicals from $\mathrm{O}_{3}$ are generally thought to follow either the Hoigne, Staehelin, and Bader model (Hoigne and Bader, 1983a; Hoigne and Bader, 1983b; Hoigne et al., 1985) or the Tomiyasu, Fukutomi, and Gordan model (Tomiyasu et al., 1985) mechanisms (Clayton et al., 2011). Although, indirect oxidation using radical formation is highly reactive, this pathway may be limited in the presence of radical scavengers. 
Use of oxidant stabilizers has been considered for increased oxidant stability and transportability within the subsurface (Huling and Pivetz, 2006). Oxidant stabilization generally involves addition of a chemical that forms a complex with an oxidant, which limits oxidant reactivity. Stabilizers have been developed mainly for iron (i.e., chelators) and hydrogen peroxide $\left(\mathrm{H}_{2} \mathrm{O}_{2}\right)$ (i.e., phosphates or organic acids) (Watts et al., 2007). These modified-Fenton reaction methods then utilize a facilitated-transport approach to deliver the oxidant to the organic contaminants (Lee and Lee, 2010; Lewis et al., 2009; Lindsey et al., 2003; Wang and Brusseau, 1998).

Clathrates such as cyclodextrins have been shown to enhance the solubility and transport of both organics and metals (e.g., Blanford et al., 2014; Boving and McCray, 2000; Boving et al., 1999; Brusseau et al., 1994; Brusseau et al., 1997; Carroll and Brusseau, 2009; Chatain et al., 2004; Fourmentin et al., 2007; Gao et al., 2013; McCray et al., 2000; Skold et al., 2007; Tick et al., 2003; Wang and Brusseau, 1995). Cyclodextrins have also been used to complex iron, preventing the consumption of $\mathrm{H}_{2} \mathrm{O}_{2}$ and precipitation of iron (Lindsey et al., 2003). A ternary complex between the specific cyclodextrin called hydroxypropyl- $\beta$-cyclodextrin $(\mathrm{HP} \beta \mathrm{CD}), \mathrm{Fe}^{2+}$, and pollutants has been observed (Liang et al., 2007). Veignie et al. demonstrated that certain cyclodextrins increase contaminant solubility while simultaneously supporting their degradation by Fenton's reaction (Veignie et al., 2009). It has been hypothesized that the formation of a ternary complex (i.e., pollutant-cyclodextrin-iron) enhances contaminant degradation by increasing the proximity of the contaminant to the $\mathrm{OH} \bullet$ radical (Lindsey et al., 2003; Veignie et al., 2009). 
$\mathrm{O}_{3}$ is relatively hydrophobic, and could potentially be attracted to the hydrophobic cavity of $\mathrm{HP} \beta C D$. The oxidative transformation of glucose with $\mathrm{O}_{3}$ is well known (Marcq et al., 2009), and therefore destruction of $\mathrm{HP} \beta C D$ (i.e., a ring of glucose molecules) would be expected. However, HP $\beta C D$ is generally more recalcitrant than the glucose building blocks, e.g. they are resistant to biological decay for a period of at least a few months (Wang et al., 1998). Prior work has not examined the potential for $\mathrm{O}_{3}$ or other strong oxidants to oxididize HP $\beta C D$. Thus, it is currently unknown if and to what extend $\mathrm{O}_{3}$ can degrade $\mathrm{HP} \beta C D$ and what transformation products are formed in the process. Examination of the potential for $\mathrm{O}_{3}$ to transform $\mathrm{HP} \beta C D$ and/or for $\mathrm{HP} \beta C D$ to form a complex with $\mathrm{O}_{3}$ is examined herein.

It is hypothesized that aqueous phase $\mathrm{O}_{3}$ partitions into the cavity of the $\mathrm{HP} \beta C D$ molecule, and that the formation of a $\mathrm{HP} \beta \mathrm{CD}: \mathrm{O}_{3}$ inclusion complex (i.e., one chemical compound forms a cavity in which molecules of a second "guest" compound are located) prolongs the reactivity of $\mathrm{O}_{3}$ in groundwater solutions. The objective of this research was to examine the potential for complexation of $\mathrm{O}_{3}$ by $\mathrm{HP} \beta \mathrm{CD}$, as suggested previously (Ball, 2011), and the resulting impact on the stabilization and prolonged reactivity of the $\mathrm{O}_{3}$. Because HP $\beta C D$ is a cyclic sugar, consisting of glucose molecules, it must be expected that the $\mathrm{HP} \beta C D$ molecule is susceptible to oxidation. Therefore, the potential for $\mathrm{O}_{3}$ to transform $\mathrm{HP} \beta C \mathrm{CD}$ was studied in aqueous-phase batch experiments. The ultimate goal was to provide insights into $\mathrm{O}_{3}$ complexation by $\mathrm{HP} \beta \mathrm{CD}$ and related facilitated transport processes that potentially extends the reactive lifetime and lateral 
reach of $\mathrm{O}_{3}$ in subsurface environments. Such a technology could support ISCO remediation of groundwater contaminated with recalcitrant compounds.

\section{MATERIALS AND METHODS}

\subsection{Materials}

Hydroxypropyl- $\beta$-cyclodextrin, or $\mathrm{HP} \beta \mathrm{CD},(90 \%$ purity technical grade; average molecular weight: $1375 \mathrm{~g} \mathrm{~mol}^{-1}$ ) was purchased from Sigma-Aldrich (Milwaukee, WI. Lot \#BCBK6962V). A Barnstead NANOpure II (Series 550, Dubuque, Iowa) system was used to purify water used for all solutions to $>18 \mathrm{M} \Omega-\mathrm{cm}$ (termed DI). A synthetic groundwater solution (Table 1) containing $9 \mathrm{mg} / \mathrm{L} \mathrm{Ca}\left(\mathrm{NO}_{3}\right)_{2}, 85 \mathrm{mg} / \mathrm{L} \mathrm{CaCl}_{2}, 124 \mathrm{mg} / \mathrm{L}$ $\mathrm{MgSO}_{4}, 171 \mathrm{mg} / \mathrm{L} \mathrm{NaHCO}_{3}$, and $20 \mathrm{mg} / \mathrm{L} \mathrm{NaCl}$ prepared in DI was used for all experiments except when noted that DI was used. The synthetic groundwater represents the chemistry of the contaminated groundwater at Air Force Plant 44 (AFP44) in Tucson, Arizona, USA (Matthieu et al., 2013). All experiments were conducted at $20( \pm 1)^{\circ} \mathrm{C}$. Gasphase $\mathrm{O}_{3}$ was generated using a G-series Pacific Ozone Generator (model \#G1110101, Benicia, California), which was sparged through aqueous solutions to dissolve $\mathrm{O}_{3}$ before each experiment.

\subsection{Chemical analysis}

Aqueous $\mathrm{O}_{3}$ concentrations were determined by the indigo method (Bader and Hoigné, 1981) using a Milton Roy Spectronic 401 spectrophotometer, which has a reported precision to be $2 \%$ or $3 \mu \mathrm{g} / \mathrm{L}$ for $\mathrm{O}_{3}$ analysis. Aqueous $\mathrm{HP} \beta \mathrm{CD}$ samples were 
analyzed for concentration by fluorescence methods (Kondo et al., 1976) using a LS-55 Perkin Elmer spectrofluorometer. UV-Vis spectroscopy wavelength scans were also used to confirm $\mathrm{HP} \beta \mathrm{CD}: \mathrm{O}_{3}$ complexation (SpectraMax M2, Molecular Devices). Additionally, HP $\beta C D$ samples were analyzed for concentration and for identification of transformation products, by positive-ion electrospray ionization (ESI) Fourier transform ion cyclotron resonance (FT-ICR) mass spectrometry (MS), performed with a hybrid linear ion trap $7 \mathrm{~T}$ FT-ICR mass spectrometer (LTQ FT, Thermo, San Jose, CA). The mass spectrometer was equipped with a chip-based nano-electrospray ionization and sample-handling robot (Advion Triversa NanoMate) to produce positively- and negatively-charged ions. Prior to mass spectral analysis, samples were diluted 2-fold in methanol that contained $0.1 \%$ formic acid and $0.3 \mu \mathrm{M}$ reserpine as an internal standard for signal normalization. Mass spectra were collected at a mass range of $300-2000 \mathrm{~m} / \mathrm{z}$ and at mass resolving power of $\mathrm{m} / \Delta \mathrm{m}_{50 \%}=400,000(\mathrm{~m} / \mathrm{z} 400)$. Internal mass calibration of FT-ICR mass spectra produces sub-part-per-million mass measurement accuracy, and enables the direct determination of elemental composition from measured mass to charge ratios. Thus, compounds were identified at the level of elemental composition based on accurate mass measurement by FT-ICR MS and linear ion trap mass spectra were used for relative quantitation. Peak lists generated from linear ion trap mass spectra were normalized to the internal standard signal by summation of all signals for doubly-charged HP $\beta C D$ ions (singly-charged ions were not observed for all samples) and division by the internal standard signal intensity. 


\subsection{Ozone decay experiments}

Batch, time-series experiments were conducted to measure the decay kinetics of $\mathrm{O}_{3}$ in $\mathrm{HP} \beta C D$ solutions. For this, solutions were prepared spanning concentration ranges from 0 to $62.5 \mu \mathrm{M}(3.0 \mathrm{mg} / \mathrm{L}) \mathrm{O}_{3}$ and 2.2 to $727 \mu \mathrm{M}(3 \mathrm{mg} / \mathrm{L}$ to $1 \mathrm{~g} / \mathrm{L}) \mathrm{HP} \beta C D$ by mixing separate solutions each containing $\mathrm{O}_{3}$ or $\mathrm{HP} \beta C D$ which were combined, mixture concentrations were measured, and mixed solutions were agitated for up to 70 hours. All tests were conducted in triplicate, including two control experiments (i.e., no HP $\beta C D$ ), using synthetic groundwater and $125 \mathrm{~mL}$ amber VOA vials without headspace. The vials were sampled sacrificially at predetermined time intervals with a gastight syringe (Hamilton Company, Reno, Nevada), followed by immediate $\mathrm{O}_{3}$ analysis by the indigo method. Results within the $95 \%$ confidence intervals are reported. The $\mathrm{pH}$, temperature, and oxidation-reduction potential (ORP) were also measured. Samples collected at the end of these experiments and additional mixtures prepared at various $\operatorname{HP} \beta C D(5-500 \mathrm{mg} /$ $\mathrm{L} ; 3.64-364 \mu \mathrm{M})$ and $\mathrm{O}_{3}(0.5-2 \mathrm{mg} / \mathrm{L} ; 10.4-41.6 \mu \mathrm{M})$ concentrations were analyzed for HP $\beta C D$ and transformation products.

\subsection{Ozone stabilization experiments}

The stabilization, longevity, and prolonged reactivity of $\mathrm{O}_{3}$ in $\mathrm{HP} \beta \mathrm{CD}$ solution was measured in batch, time-series experiments. The primary difference between these and the Section $2.3 \mathrm{O}_{3}$ decay experiments was that during the $\mathrm{O}_{3}$ stabilization experiments indigo was present in the batch reactors and concentrations of indigo were monitored over time rather than $\mathrm{O}_{3}$ concentrations. Equal volumes of freshly prepared $\mathrm{O}_{3}$ 
and $\mathrm{HP} \beta C D$ solutions were mixed in $125 \mathrm{~mL}$ amber VOA vials containing $10 \mathrm{~mL}$ of a potassium indigo trisulfonate (without headspace). Control experiments were conducted to monitor the natural indigo decay in the absence of $\mathrm{O}_{3}$. At predetermined times triplicate samples were collected and analyzed for indigo, the $95 \%$ confidence interval was calculated, and subsamples were monitored for $\mathrm{pH}$, temperature, and ORP.

\section{RESULTS AND DISCUSSION}

\subsection{Ozone transformation of HP $\beta C D$}

The potential for transformation of $\mathrm{HP} \beta C D$ by $\mathrm{O}_{3}$ was examined using linear ion trap relative quantitation of $\mathrm{HP} \beta C D$ by broadband positive-ion ESI FT-ICR mass spectroscopy with and without $\mathrm{O}_{3}$ exposure. Fig. 1 presents the resulting HP $\beta C D$ relative concentration for various initial HP $\beta C D$ concentrations, and experiments with identical $\mathrm{HP} \beta C D$ solution concentrations before and after exposure to $\mathrm{O}_{3}$ are compared. Fig. 1A, $1 \mathrm{~B}$, and $1 \mathrm{C}$ contain results for $\mathrm{HP} \beta \mathrm{CD}$ exposed to $\mathrm{O}_{3}$ concentrations of $0.5 \mathrm{mg} / \mathrm{L}(10.4$ $\mu \mathrm{M}), 1 \mathrm{mg} / \mathrm{L}(20.8 \mu \mathrm{M})$, and $2 \mathrm{mg} / \mathrm{L}(41.7 \mu \mathrm{M})$, respectively. The HP $\beta C D$ relative concentration was generally reduced relative to the result without $\mathrm{O}_{3}$ exposure, which confirms that $\mathrm{O}_{3}$ does react with $\mathrm{HP} \beta C D$ and the decreased HP $\beta C D$ concentrations are due to transformation of $\mathrm{HP} \beta C D$ by $\mathrm{O}_{3}$. However, only a fraction of $\mathrm{HP} \beta C D$ was transformed during this reaction.

Fig. 2 shows the percentage of $\mathrm{HP} \beta C D$ transformed as a function of the $\mathrm{O}_{3}: \mathrm{HP} \beta C D$ molar ratio. The results indicate that when the $\mathrm{O}_{3}: \mathrm{HP} \beta C D$ molar ratio was 
high $(>2: 1)$, as much as $76 \%$ of the $\mathrm{HP} \beta \mathrm{CD}$ was transformed. At a molar ratio of approximately $1: 1$, about $60 \%$ of the HP $\beta C D$ was transformed, whereas transformation was limited to 2 to $21 \%$ at a $1: \sim 11$ ratio. Importantly, above a $\mathrm{O}_{3}: \mathrm{HP} \beta \mathrm{CD}$ molar ratio of $2: 1$, the fraction of remaining $\operatorname{HP} \beta C D(\sim 25 \%)$ remained constant, which suggests that this fraction of the HP $\beta C D$ resisted ozonisation and apparently was stabilized, possibly by complexing $\mathrm{O}_{3}$ inside its cavity.

The interaction of $\mathrm{O}_{3}$ with $\mathrm{HP} \beta \mathrm{CD}$ at the molecular level was also studied by broadband positive-ion ESI FT-ICR mass spectroscopy. The results for synthetic groundwater treated with $250 \mathrm{mg} / \mathrm{L}(181.8 \mu \mathrm{M}) \mathrm{HP} \beta C D$ and $2 \mathrm{mg} / \mathrm{L}(41.7 \mu \mathrm{M}) \mathrm{O}_{3}$ are shown in Fig. 3a. A successive substitution of 2-hydroxypropyl groups (up to ten 2hydroxypropyl groups per molecule) to singly- and doubly-charged HP $\beta C D$ ions was observed. Sodium $\left([\mathrm{M}+\mathrm{Na}]^{+}\right)$was the predominant singly-charged ions adduct (Fig. 3b), whereas doubly-charged ions included calcium, magnesium, lithium, and potassium, as illustrated in Fig. 3c. The elemental composition assignments were confirmed by mass measurement with high-resolution FT-ICR MS, which was performed for the $\mathrm{O}_{3}$-treated (i.e., with $\mathrm{O}_{3}$ ) and control groundwater samples prepared with identical concentrations of $\mathrm{HP} \beta C \mathrm{CD}$ but without $\mathrm{O}_{3}$. Further, negative-ion mode FT-ICR mass spectra were monitored for $\mathrm{HP} \beta \mathrm{CD}$ reaction products (data not shown). The HP $\beta \mathrm{CD}$ concentration decreased, and each hydroxypropyl group decreased without observing the formation of reaction/ oxidation products or removal of any one of the hydroxypropyl peaks (Fig. 3d). The sugars on $\mathrm{HP} \beta C D$ molecules have the acetal functional group which may have been 
cleaved by $\mathrm{O}_{3}$, which would result in cyclic esters and loss of chelating functionality. Together, the data indicate that ozonization mineralized (likely forming $\mathrm{CO}_{2}$ ) up to $76 \%$ of the HP $\beta C D$ but without completely eliminating the HP $\beta C D$ ion signals (Figure 2).

\subsection{Ozone decay and stabilization within HPßCD inclusion complex}

The fraction of $\mathrm{HP} \beta C D$ not mineralized by the $\mathrm{O}_{3}$ formed an inclusion complex with the oxidant, and this likely shielded the $\mathrm{HP} \beta C D$ from further transformation while stabilizing the $\mathrm{O}_{3}$. Evidence for the formation of a $\mathrm{HP} \beta C D: \mathrm{O}_{3}$ complex was discovered as a shift in UV-Vis spectroscopy wavelength scan results for solutions containing HP $\beta C D$ and $\mathrm{O}_{3}$ within DI compared to unmixed solutions at identical concentrations. Shifts in spectroscopy absorbance have previously been used to identify aqueous complexation (e.g., Jung et al., 2013; Liang et al., 2007). Fig. 4 presents the absorbance data versus wavelength for solutions containing $20 \mathrm{~g} / \mathrm{L}(14.5 \mathrm{mM}) \mathrm{HP} \beta \mathrm{CD}$ with and without $6 \mathrm{mg} / \mathrm{L}$ $(0.125 \mathrm{mM}) \mathrm{O}_{3}$. The spectrophotometric wavescan absorbance shifted for the HP $\beta C D$ peak at $205 \mathrm{~nm}$ upon addition of $\mathrm{O}_{3} . \mathrm{HP} \beta \mathrm{CD}$ adsorbs at $205 \mathrm{~nm}\left(\mathrm{O}_{3}\right.$ absorbs at $\left.260 \mathrm{~nm}\right)$, and the absorbance at $205 \mathrm{~nm}$ increased with addition of $\mathrm{O}_{3}$ compared to the scan without $\mathrm{O}_{3}$. After 3 days, the sample was reanalyzed and the peak at $205 \mathrm{~nm}$ had reduced absorbance relative to the scan after $\mathrm{O}_{3}$ was added, and became comparable to the initial scan before the $\mathrm{O}_{3}$ was added. The increase in absorbance at the HP $\beta C D$ wavelength upon $\mathrm{O}_{3}$ addition suggests that $\mathrm{O}_{3}$ and $\mathrm{HP} \beta \mathrm{CD}$ form an inclusion complex, and this is confirmed by the isosbetic (wavelength crossover) point at $210 \mathrm{~nm}$. Additionally, the 
reduction of the absorbance back to the level observed without $\mathrm{O}_{3}$ addition, suggests that $\mathrm{O}_{3}$ left the HP $\beta C D$ cavity and was decayed through reaction with aqueous hydroxide to form hydroxyl radicals over time. Based on the $\mathrm{O}_{3}$ half-life in water (Table 2), the $\mathrm{O}_{3}$ would have been completely degraded after the 3 days. These data confirm that the $\mathrm{HP} \beta C D: \mathrm{O}_{3}$ complexation forms, and is also reversible. The mechanism that is generally accepted for inclusion-complex formation within the HP $\beta C D$ cavities is hydrophobic partitioning (Connors, 1997). Partitioning of $\mathrm{O}_{3}$ into the HP $\beta C D$ cavity can also be attributed to this mechanism, because of the hydrophobicity and low polarity of $\mathrm{O}_{3}$. This is analogous to hydrophobic partitioning of low polarity compounds into surfactant micelles or to the surface of low polarity organic matter, and this partitioning is generally considered to be a weak attraction force that is generally reversible.

$\mathrm{O}_{3}$ decay was studied in DI water and synthetic groundwater with and without HP $\beta C D$. The decay followed pseudo $1^{\text {st }}$-order reaction kinetics in the synthetic groundwater with and without $\mathrm{HP} \beta \mathrm{CD}$ (Fig. 5a and 5b). In HP $\beta \mathrm{CD}$ free groundwater, the dissolved $\mathrm{O}_{3}$ half-life was $0.43-0.37$ hours $\left(\mathrm{k}=1.6-1.9\right.$ hours $\left.^{-1}\right)$ (Table 2), confirming literature values for groundwater/ $\mathrm{O}_{3}$ systems. In DI water, the $\mathrm{O}_{3}$ half-life approximately tripled (1.4 hours). The more rapid decay in the synthetic groundwater is attributed to the slightly basic $\mathrm{pH}$ (7.9) and the presence of salts, which may act as radical scavengers (e.g., Rużyłło et al., 1998).

The half-life of $\mathrm{O}_{3}$ in groundwater solutions with an overabundance of $\mathrm{HP} \beta C D$ increased to 6.73 hours $\left(\mathrm{k}=0.103\right.$ hours $^{-1}$ at $\mathrm{HP} \beta \mathrm{CD}: \mathrm{O}_{3}$ mole ratios of 17.5:1) and 14.75 
hours $\left(\mathrm{k}=0.047\right.$ hours $^{-1}$ at $\mathrm{HP} \beta \mathrm{CD}: \mathrm{O}_{3}$ mole ratios of 34.6:1), respectively. The $\mathrm{O}_{3}$ halflife and $\mathrm{HP} \beta \mathrm{CD}: \mathrm{O}_{3}$ mole ratios were linearly related (Fig. 6). The addition of $\mathrm{HP} \beta \mathrm{CD}$ to water does decrease the $\mathrm{pH}$ by 1 to 2 units and this alone can increase $\mathrm{O}_{3}$ half-life. However, this effect was similar to, or less than, the half-life difference observed for DI water compared to groundwater, and cannot account for the half-life increase of up to a factor of $\sim 40$ observed with $\mathrm{HP} \beta C D$.

\subsection{Ozone stabilization and release from the HPßCD inclusion complex}

The cumulative $\mathrm{O}_{3}$ mass release from the $\mathrm{HP} \beta \mathrm{CD}: \mathrm{O}_{3}$ complex and stabilization of the oxidant in aqueous phase was investigated with the indigo indicator in solution in a series of experiments with $\mathrm{HP} \beta \mathrm{CD}: \mathrm{O}_{3}$ molar ratios ranging from 873:1 $(20 \mathrm{~g} / \mathrm{L}$ or 14.5 $\mu \mathrm{M}$ HP $\beta C D$ with $0.8 \mathrm{mg} / \mathrm{L}$ or $\left.0.017 \mu \mathrm{M} \mathrm{O}_{3}\right)$ to $10: 1(0.17 \mathrm{~g} / \mathrm{L}$ or $0.12 \mu \mathrm{M} \mathrm{HP} \beta C D$ with $0.6 \mathrm{mg} / \mathrm{L}$ or $0.013 \mu \mathrm{M} \mathrm{O}_{3}$ ). The compilation of results from these 9 experiments are summarized in Fig. 7, which displays the cumulative increase of free dissolved $\mathrm{O}_{3}$ over time as indicated by continuous reaction with indigo (i.e., $\mathrm{O}_{3}$ indicator and model contaminant). Control experiments (without $\mathrm{O}_{3}$; data not shown) confirmed that indigo concentration did not change with $\mathrm{HP} \beta \mathrm{CD}$ addition, i.e. there was no evidence for the removal of indigo through either decay or complexation with $\mathrm{HP} \beta C D$.

These results show that for the duration of the experiments ( $>70$ hours), $\mathrm{O}_{3}$ was continuously released from the $\mathrm{HP} \beta \mathrm{CD}$ and that the $\mathrm{O}_{3}$ remained reactive, as indicated by the destruction of the indigo throughout the experiment. This confirms that the formation 
of the $\mathrm{HP} \beta \mathrm{CD}: \mathrm{O}_{3}$ inclusion complexation is a reversible process and, importantly, that the $\mathrm{O}_{3}$ reactivity was conserved during the period of inclusion. For comparison, in aqueous solutions without $\mathrm{HP} \beta \mathrm{CD}, \mathrm{O}_{3}$ is only reactive and measurable for $\sim 5-6$ hours (i.e., $1 / 2$ hour half-life), and $\mathrm{O}_{3}$ in solution with $\mathrm{HP} \beta C D$ had prolonged reactivity of over an order of magnitude (i.e., $>70$ hours), which is comparable to results of the other batch $\mathrm{O}_{3}$ decay experiments. The data also indicate that a large fraction of the $\mathrm{O}_{3}$ initially present was released, and the fraction of released $\mathrm{O}_{3}$ increased with increasing $\mathrm{HP} \beta \mathrm{CD}: \mathrm{O}_{3}$ molar ratio. This finding has important implications for possible future application of this oxidant stabilization and delivery method.

Starting with a comparatively low initial $\mathrm{O}_{3}$ concentration (e.g., $0.6 \mathrm{mg} / \mathrm{L}$ or 0.013 $\mathrm{mM}$ ) the rate of $\mathrm{O}_{3}$ release slowed down toward the end of the experiment. This indicates when using low initial $\mathrm{O}_{3}$ concentrations a large fraction of the $\mathrm{O}_{3}$ was lost, either due to decay within the HP $\beta C D$ cavity or because of oxidative transformation of the HP $\beta C D$. However, reactivity did persist even in these experiments for $\sim 70$ hours, which further supports that released $\mathrm{O}_{3}$ would be available for reaction with contaminants as indicated by the observed indigo transformation. The results support the hypothesis that the partitioning of $\mathrm{O}_{3}$ into the $\mathrm{HP} \beta C D$ cavity can, in fact, stabilize the reactivity of $\mathrm{O}_{3}$ in groundwater solutions.

\subsection{Implications for in-situ chemical oxidation of contaminated groundwater}

This study demonstrates that the application of HP $\beta C D$ to groundwater solutions containing $\mathrm{O}_{3}$ can potentially enhance the oxidant lifespan and prolong oxidant reactivity 
for days and thereby can possibly improve the oxidant delivery farther away from the injection location. This would enhance the radius of influence of the ISCO treatment beyond what is currently possible when injecting aqueous $\mathrm{O}_{3}$ into the subsurface. Coinjection of $\mathrm{HP} \beta C D$ with $\mathrm{O}_{3}$ into groundwater would increase the $\mathrm{O}_{3}$ transport distance by more than an order of magnitude, which could be applied as a source-treatment alternative, and it could be used to maintain a reactive flow-through treatment for groundwater contamination plumes. $\mathrm{As}_{2} \mathrm{H}_{2} \mathrm{O}_{2}$ stabilization using organic-acid stabilizers has been demonstrated previously (Watts et al., 2007), this $\mathrm{HP} \beta \mathrm{CD}: \mathrm{O}_{3}$ complex may also support ISCO using perozone reactions.

The focus of this study was on aqueous reactions without adding further complexity of potential reactions between aqueous and solid mineral phases, which would need to be considered for implementation of ISCO treatment of groundwater contaminants. We acknowledge that the presence of organic matter, iron, manganese, and other redox-sensitive mineral phases in natural sediments might affect the lifetime of $\mathrm{O}_{3}$ in the subsurface with and without the addition of cyclodextrins including HP $\beta C D$. Further investigation is ongoing that includes natural, metal oxide containing minerals. As noted previously, radical scavengers, such as transition metals and soil organic matter associated with the subsurface materials, both aqueous and solid, can impose a significant oxidant demand. However, oxidant stabilizers, such as a $\mathrm{HP} \beta \mathrm{CD}: \mathrm{O}_{3}$ complex, may potentially inhibit reactivity of oxidants with reactive solid minerals by shielding a fraction of the oxidant within the $\mathrm{HP} \beta C D$ cavity. Stabilization may also increase the potential for enhanced reaction selectivity. For the HP $\beta C D: \mathrm{O}_{3}$ inclusion complex, 
nonpolar contaminants, such as chlorinated solvents, might compete with $\mathrm{O}_{3}$ to occupy the HP $\beta C D$ cavity, which may potentially increase the selectivity of using $\mathrm{O}_{3}$ for the oxidation of those types of contaminants.

\section{SUMMARY}

The results of this investigation support the hypothesis that $\mathrm{HP} \beta \mathrm{CD}$ forms an inclusion complex with $\mathrm{O}_{3}$, and the partitioning of $\mathrm{O}_{3}$ into the $\mathrm{HP} \beta C D$ cavity can, in fact, stabilize and prolong the reactivity of $\mathrm{O}_{3}$ in groundwater solutions. In particular, it was discovered that $\mathrm{HP} \beta C D$ was only partially degraded by $\mathrm{O}_{3}$, and that a fraction of the $\mathrm{HP} \beta C D$ formed a $\mathrm{HP} \beta C D: \mathrm{O}_{3}$ inclusion complex. This complex stabilized $\mathrm{O}_{3}$ and increased the lifespan of $\mathrm{O}_{3}$ in groundwater solutions containing HP $\beta C D$ by a factor of up to 40 , relative to $\mathrm{HP} \beta C D$-free solutions. The $\mathrm{O}_{3}$ half-life enhancement was linearly related to the $\mathrm{HP} \beta \mathrm{CD}: \mathrm{O}_{3}$ molar ratio. Also, the formation of the inclusion complex was reversible, which stabilized $\mathrm{O}_{3}$ and sustained indigo transformation (used herein as an indicator and model contaminant), and it prolonged $\mathrm{O}_{3}$ reactivity. The results reported in this study have implications for development of facilitated-transport enabled ISCO using strong oxidants for the treatment of groundwater contaminated with various recalcitrant compounds including 1,4-dioxane. Although these results support our understanding of $\mathrm{O}_{3}$ based ISCO, it is important to note that the laboratory-scale results presented herein may not directly translate to field-scale conditions. 


\section{Acknowledgements}

This research was primarily supported by the US Department of Defense Strategic Environmental Research and Development Program (SERDP) Project ER-2302. Additional support from USDA National Institute of Food and Agriculture (Hatch project 1006845), the U.S. Air Force Civil Engineer Center (AFCEC) Project FA8903-11C-8004, the United States National Science Foundation (IIA-1301346), the Center for Animal Health and Food Safety, and the Plant \& Environmental Science Department at NMSU is appreciated. EnChem Engineering, Inc.'s patent was utilized herein (US Patent $8,049,056)$. We also appreciate the support of Omar Holguin, Barry Dungan, Alan Moore, Barbara Hunter, Sativa Cruz, April Ulery, Michael Johnson, Mark Brusseau, and members of the Carroll Lab. 


\section{REFERENCES}

Bader, H. and Hoigné, J., 1981. Determination of ozone in water by the indigo method. Water Research, 15(4): 449-456.

Ball, R.G., 2011. Chemical oxidation method and compounds, US Patent 8,049,056. Enchem Engineering, Inc., US.

Bhuyan, S.J. and Latin, M.R., 2012. BTEX Remediation under Challenging Site Conditions Using In-Situ Ozone Injection and Soil Vapor Extraction Technologies: A Case Study. Soil and Sediment Contamination: An International Journal, 21: 545--556.

Blanford, W.J., Gao, H., Dutta, M. and Ledesma, E.B., 2014. Solubility enhancement and QSPR correlations for polycyclic aromatic hydrocarbons complexation with alpha, beta, and gamma cyclodextrins. Journal of Inclusion Phenomena and Macrocyclic Chemistry, 78(1-4): 415-427.

Boving, T.B. and McCray, J.E., 2000. Cyclodextrin-Enhanced Remediation of Organic and Metal Contaminants in Porous Media and Groundwater. Remediation Journal, 10(2): 59-83.

Boving, T.B., Wang, X.J. and Brusseau, M.L., 1999. Cyclodextrin-enhanced solubilization and removal of residual-phase chlorinated solvents from porous media. Environmental Science and Technology, 33(5): 764-770.

Brusseau, M.L. et al., 2011. Impact of In Situ Chemical Oxidation on Contaminant Mass Discharge: Linking Source-Zone and Plume-Scale Characterizations of Remediation Performance. Environmental Science \& Technology, 45(12): 5352-5358.

Brusseau, M.L., Wang, X. and Hu, Q., 1994. Enhanced transport of low-polarity organic compounds through soil by cyclodextrin. Environmental Science and Technology, 28: 952--956.

Brusseau, M.L., Wang, X.J. and Wang, W.Z., 1997. Simultaneous elution of heavy metals and organic compounds from soil by cyclodextrin. Environmental Science \& Technology, 31(4): 1087-1092.

Carroll, K.C. and Brusseau, M.L., 2009. Dissolution, cyclodextrin-enhanced solubilization, and mass removal of an ideal multicomponent organic liquid. Journal of Contaminant Hydrology, 106(1-2): 62-72. 
Chatain, V., Hanna, K., de Brauer, C., Bayard, R. and Germain, P., 2004. Enhanced solubilization of arsenic and 2,3,4,6 tetrachlorophenol from soils by a cyclodextrin derivative. Chemosphere, 57(3): 197-206.

Clayton, W.S., Petri, B.G. and Huling, S.G., 2011. Fundamentals of ISCO Using Ozone. In: R.L. Siegrist (Editor), In Situ Chemical Oxidation for Groundwater Remediation. Springer Science+Business Media, LLC.

Connors, K.A., 1997. The stability of cyclodextrin complexes in solution. Chemical Reviews, 97(5): 1325-1357.

Crimi, M.L. and Siegrist, R.L., 2003. Geochemical effects on metals following permanganate oxidation of DNAPLs. Ground Water, 41(4): 458-469.

Fourmentin, S. et al., 2007. Solubilisation of chlorinated solvents by cyclodextrin derivatives - A study by static headspace gas chromatography and molecular modelling. Journal of Hazardous Materials, 141(1): 92-97.

Gao, H., Blanford, W.J. and Gao, A.F., 2013. Solubility Enhancement Effect of Cyclodexin on Groundwater Pollutants. Ground Water, 51(2): 268-275.

Hoigne, J. and Bader, H., 1983a. Rate Constants of Reactions of Ozone with Organic and Inorganic-Compounds in Water .1. Non-Dissociating Organic-Compounds. Water Research, 17(2): 173-183.

Hoigne, J. and Bader, H., 1983b. Rate Constants of Reactions of Ozone with Organic and Inorganic-Compounds in Water .2. Dissociating Organic-Compounds. Water Research, 17(2): 185-194.

Hoigne, J., Bader, H., Haag, W.R. and Staehelin, J., 1985. Rate Constants of Reactions of Ozone with Organic and Inorganic-Compounds in Water .3. InorganicCompounds and Radicals. Water Research, 19(8): 993-1004.

Huling, S. and Pivetz, B., 2006. Engineering Issue Paper: In-Situ Chemical Oxidation. Engineering: 1--60.

Jung, Y., Park, J.Y., Ko, S.O. and Kim, Y.H., 2013. Stabilization of hydrogen peroxide using phthalic acids in the Fenton and Fenton-like oxidation. Chemosphere, 90: 812--819.

Kondo, H., Nakatani, H. and Hiromi, K., 1976. Interaction of Cyclodextrins with Fluorescent-Probes and Its Application to Kinetic Studies of Amylase. Journal of Biochemistry, 79(2): 393-405. 
Lee, Y. and Lee, W., 2010. Degradation of trichloroethylene by Fe(II) chelated with cross-linked chitosan in a modified Fenton reaction. Journal of Hazardous Materials, 178(1-3): 187-193.

Lewis, S. et al., 2009. Chelate-Modified Fenton Reaction for the Degradation of Trichloroethylene in Aqueous and Two-Phase Systems. Environmental Engineering Science, 26(4): 849-859.

Liang, C.J., Huang, C.F., Mohanty, N., Lu, C.J. and Kurakalva, R.M., 2007. Hydroxypropyl-beta-cyclodextrin-mediated iron-activated persulfate oxidation of trichloroethylene and tetrachloroethylene. Industrial \& Engineering Chemistry Research, 46(20): 6466-6479.

Lim, H.N., Choi, H., Hwang, T.M. and Kang, J.W., 2002. Characterization of ozone decomposition in a soil slurry: kinetics and mechanism. Water Research, 36(1): 219-229.

Lindsey, M.E., Xu, G., Lu, J. and Tarr, M.A., 2003. Enhanced Fenton degradation of hydrophobic organics by simultaneous iron and pollutant complexation with cyclodextrins. Science of the Total Environment, 307: 215--229.

Marble, J.C., Carroll, K.C., Janousek, H. and Brusseau, M.L., 2010. In situ oxidation and associated mass-flux-reduction/mass-removal behavior for systems with organic liquid located in lower-permeability sediments. Journal of contaminant hydrology, 117(1-4): 82--93.

Marcq, O., Barbe, J.M., Trichet, A. and Guilard, R., 2009. Reaction pathways of glucose oxidation by ozone under acidic conditions. Carbohydrate Research, 344(11): 1303-1310.

Masten, S.J., 1991. Ozonation of Vocs in the Presence of Humic-Acid and Soils. OzoneScience \& Engineering, 13(3): 287-312.

Masten, S.J. and Davies, S.H.R., 1997. Efficacy of in-situ ozonation for the remediation of PAH contaminated soils. Journal of Contaminant Hydrology, 28(4): 327-335.

Matthieu, D.E. et al., 2013. Intercalation of trichloroethene by sediment-associated clay minerals. Chemosphere, 90(2): 459-463.

McCray, J.E., Boving, T.B. and Brusseau, M.L., 2000. Cyclodextrin-enhanced solubilization of organic contaminants with implications for aquifer remediation. Ground Water Monitoring and Remediation, 20(1): 94-103. 
Mumford, K.G., Lamarche, C.S. and Thomson, N.R., 2004. Natural Oxidant Demand of Aquifer Materials Using the Push-Pull Technique. Journal of Environmental Engineering, 130(October): 1139--1146.

Rużyłło, J., Division, E.S.E. and Meeting, E.S., 1998. Proceedings of the Fifth International Symposium on Cleaning Technology in Semiconductor Device Manufacturing. Electrochemical Society.

Skold, M.E., Thyne, G.D., Drexler, J.W. and McCray, J.E., 2007. Determining conditional stability constants for $\mathrm{Pb}$ complexation by carboxyrnethyl-betacyclodextrin (CMCD). Journal of Contaminant Hydrology, 93(1-4): 203-215.

Tick, G.R., Lourenso, F., Wood, A.L. and Brusseau, M.L., 2003. Pilot-scale demonstration of cyclodextrin as a solubility-enhancement agent for remediation of a tetrachloroethene-contaminated aquifer. Environmental Science \& Technology, 37(24): 5829-5834.

Tomiyasu, H., Fukutomi, H. and Gordon, G., 1985. Kinetics and Mechanism of Ozone Decomposition in Basic Aqueous-Solution. Inorganic Chemistry, 24(19): 2962-2966.

Urynowicz, M.A., 2008. In situ chemical oxidation with permanganate: Assessing the competitive interactions between target and nontarget compounds. Soil \& Sediment Contamination, 17(1): 53-62.

Veignie, E., Rafin, C., Landy, D., Fourmentin, S. and Surpateanu, G., 2009. Fenton degradation assisted by cyclodextrins of a high molecular weight polycyclic aromatic hydrocarbon benzo[a]pyrene. Journal of Hazardous Materials, 168(2-3): 1296-1301.

Wang, J., Zhang, X. and Li, G.H., 2012. Effects of ozonation on soil organic matter of contaminated soil containing residual oil. Journal of Soils and Sediments, 12(2): 117-127.

Wang, J.M., Marlowe, E.M., Miller-Maier, R.M. and Brusseau, M.L., 1998. Cyclodextrin-enhanced biodegradation of phenanthrene. Environmental Science \& Technology, 32(13): 1907-1912.

Wang, X. and Brusseau, M.L., 1995. Simultaneous complexation of organic compounds and heavy metals by a modified cyclodextrin. Environmental Science and Technology, 29(10): 2632--2635.

Wang, X.J. and Brusseau, M.L., 1998. Effect of pyrophosphate on the dechlorination of tetrachloroethene by the Fenton reaction. Environmental Toxicology and Chemistry, 17(9): 1689-1694. 
Watts, R.J., Finn, D.D., Cutler, L.M., Schmidt, J.T. and Teel, A.L., 2007. Enhanced stability of hydrogen peroxide in the presence of subsurface solids. Journal of Contaminant Hydrology, 91(3-4): 312-326.

Xu, X. and Thomson, N.R., 2009. A long-term bench-scale investigation of permanganate consumption by aquifer materials. Journal of Contaminant Hydrology, 110: 73--86.

Zenker, M.J., Borden, R.C. and Barlaz, M.A., 2003. Occurrence and Treatment of 1,4Dioxane in Aqueous Environments. Environmental Engineering Science, 20(5): 423--432.

Tables:

Table 1. Characteristics of synthetic groundwater used for all experiments.

\begin{tabular}{lcccc}
\hline Description & $\mathrm{pH}$ & $\begin{array}{c}\text { TDS } \\
(\mathrm{mg} / \mathrm{L})\end{array}$ & $\begin{array}{c}\text { Conductivity } \\
(\mu \mathrm{S} / \mathrm{cm})\end{array}$ & $\begin{array}{c}\text { Eh } \\
(\mathrm{mV})\end{array}$ \\
\hline $\begin{array}{l}\text { Synthetic } \\
\text { Groundwater }\end{array}$ & 7.9 & 379 & 565 & 212 \\
\hline Hydrogeochemistry & Major Cation & $\begin{array}{c}\text { Concentration } \\
(\mathrm{mg} / \mathrm{L})\end{array}$ & Major Anion & $\begin{array}{c}\text { Concentration } \\
(\mathrm{mg} / \mathrm{L})\end{array}$ \\
& $\mathrm{Na}$ & 54.7 & $\mathrm{Cl}$ & 66.5 \\
& $\mathrm{Ca}$ & 32.9 & $\mathrm{HCO}_{3}:$ & 99.0 \\
& $\mathrm{Mg}$ & 25.0 & $\mathrm{SO}_{4}:$ & 124.0 \\
\hline
\end{tabular}

Table 2. Comparison of ozone concentration decay pseudo $1^{\text {st }}$ order rate constants $(\mathrm{k})$ and half-life times in synthetic groundwater solutions with varying $\mathrm{HP} \beta C D$ to $\mathrm{O}_{3}$ mole ratios. "O 3 in groundwater" contains no $\mathrm{HP} \beta C D$.

\begin{tabular}{ccc}
\hline Description & ${\mathrm{k}\left(\text { hours }^{-1}\right)}$ & $\mathrm{O}_{3}$ Half-Life (hours) \\
\hline $\mathrm{O}_{3}$ in DI water & 0.49 & 1.40 \\
$\mathrm{O}_{3}$ in groundwater & 1.89 & 0.37
\end{tabular}




\begin{tabular}{ccc}
$\mathrm{O}_{3}$ in groundwater (repeat) & 1.62 & 0.43 \\
$1: 14.5\left(\mathrm{HP} \beta \mathrm{CD}: \mathrm{O}_{3}\right)$ & 1.89 & 0.37 \\
$17.5: 1\left(\mathrm{HP} \beta \mathrm{CD}: \mathrm{O}_{3}\right)$ & 0.10 & 6.73 \\
$34.6: 1\left(\mathrm{HP} \beta \mathrm{CD}: \mathrm{O}_{3}\right)$ & 0.05 & 14.8 \\
\hline
\end{tabular}


Figures: 

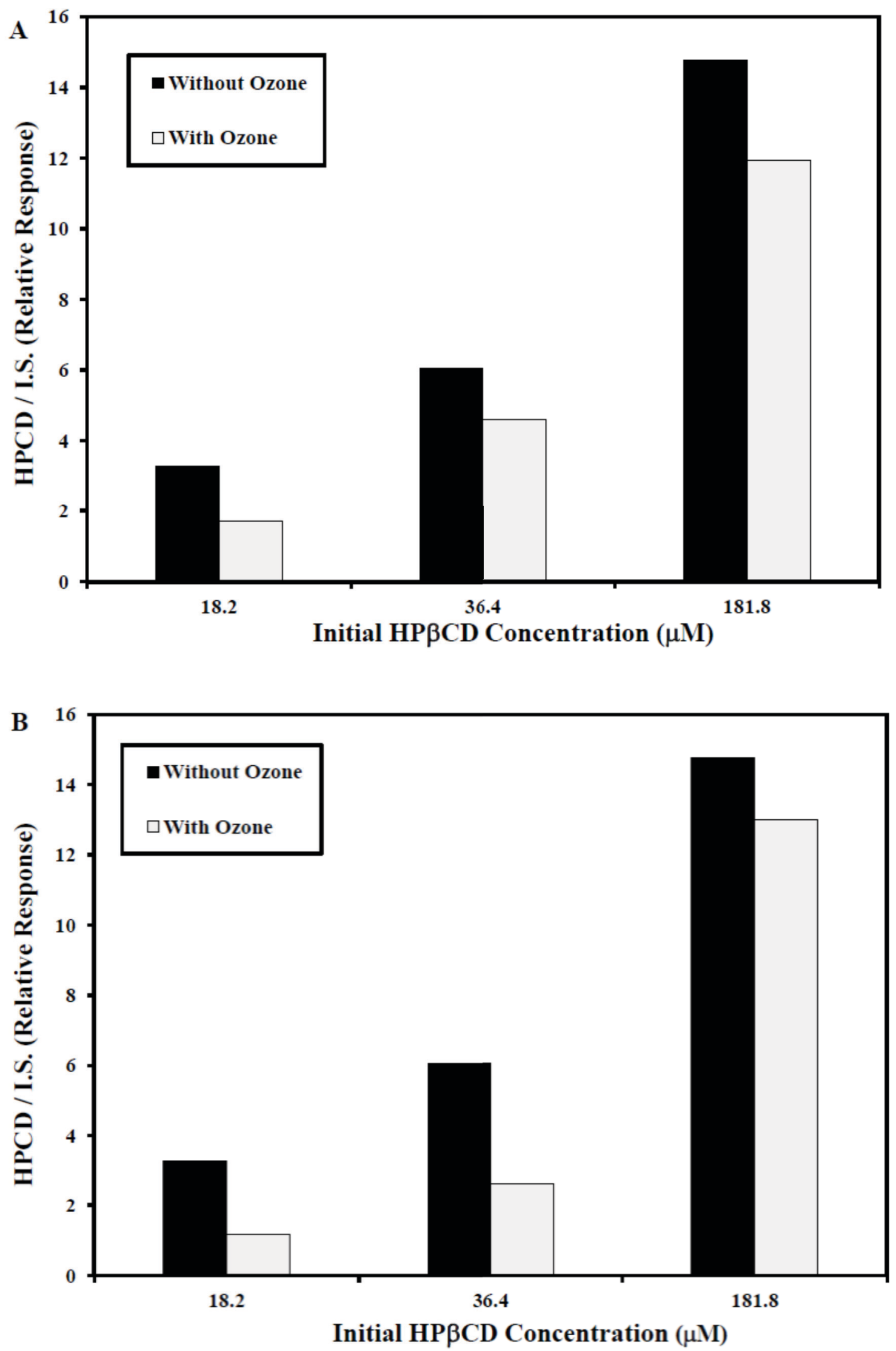


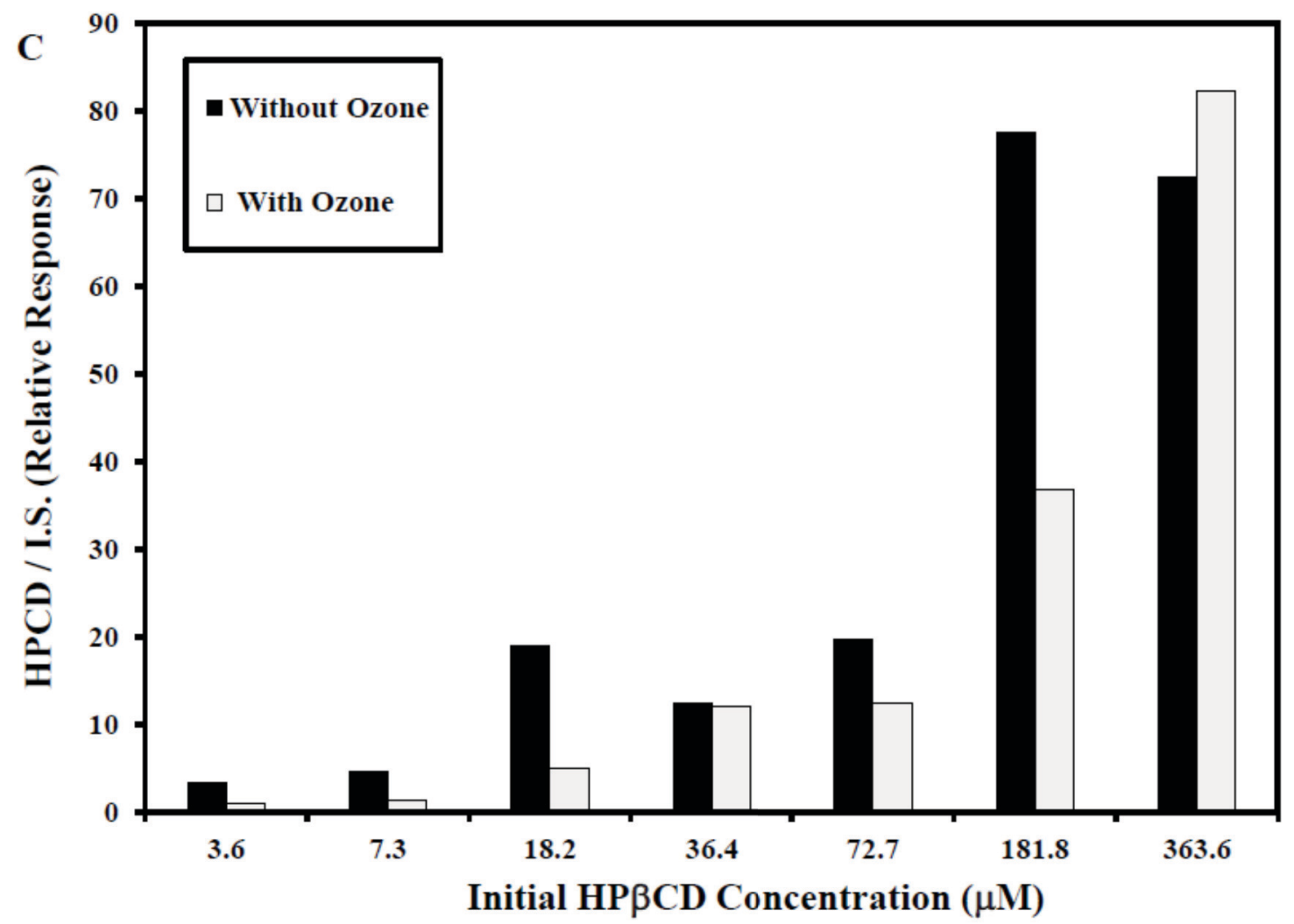

Fig. 1: Linear ion trap relative quantitation of $H P \beta C D$ with and without (A) 0.5 (10.4 $\mu \mathrm{M})$, (B) $1(20.8 \mu \mathrm{M})$, and (C) $2 \mathrm{mg} / \mathrm{L}(41.7 \mu \mathrm{M})$ ozone concentrations. (I.S. = internal standard) response. 


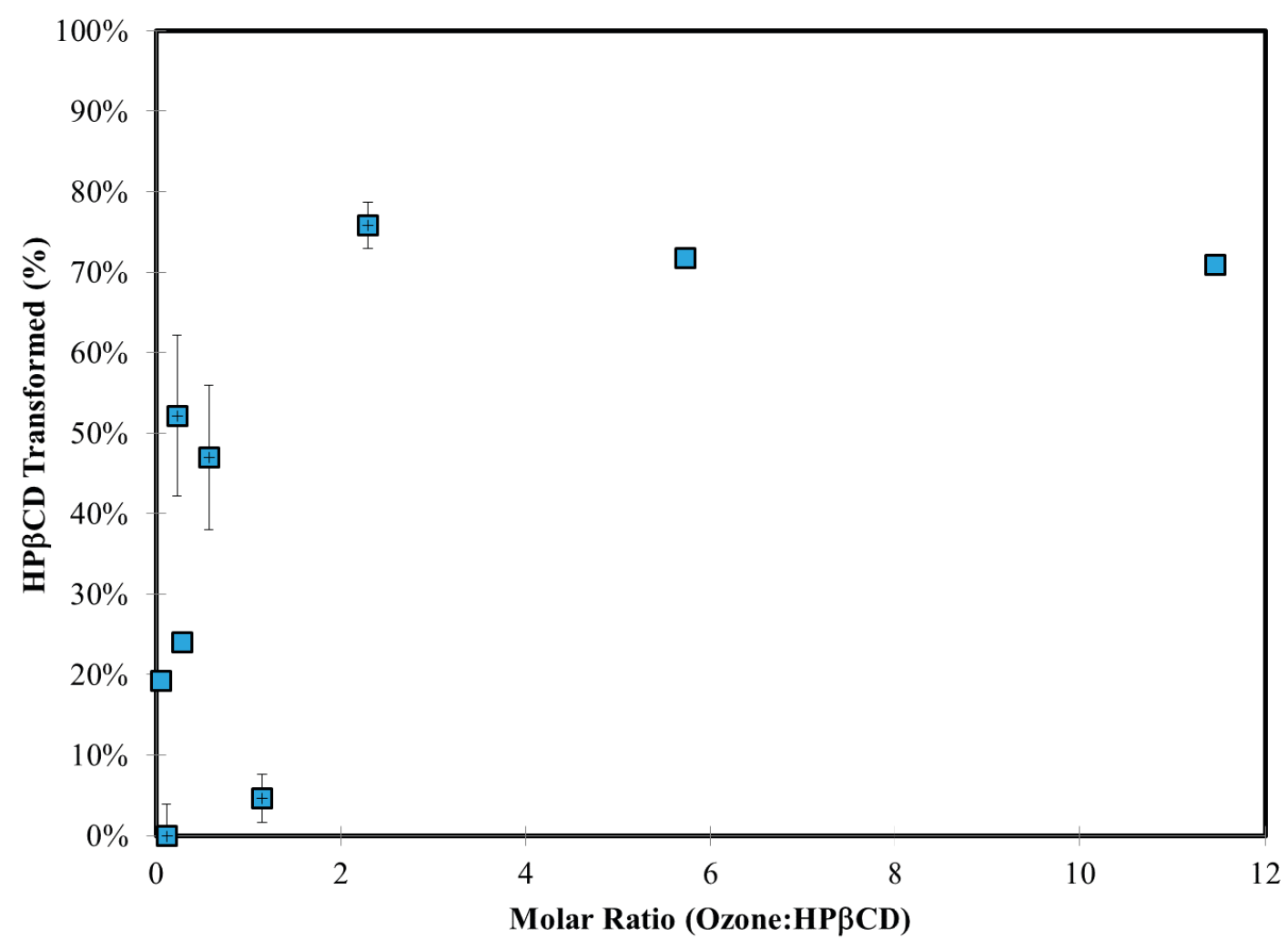

Fig. 2: Percentage of $\mathrm{HP} \beta C D$ transformed by ozone as a function of the Ozone:HP $\beta C D$ molar ratio. Error bars represent the $95 \%$ confidence intervals. 


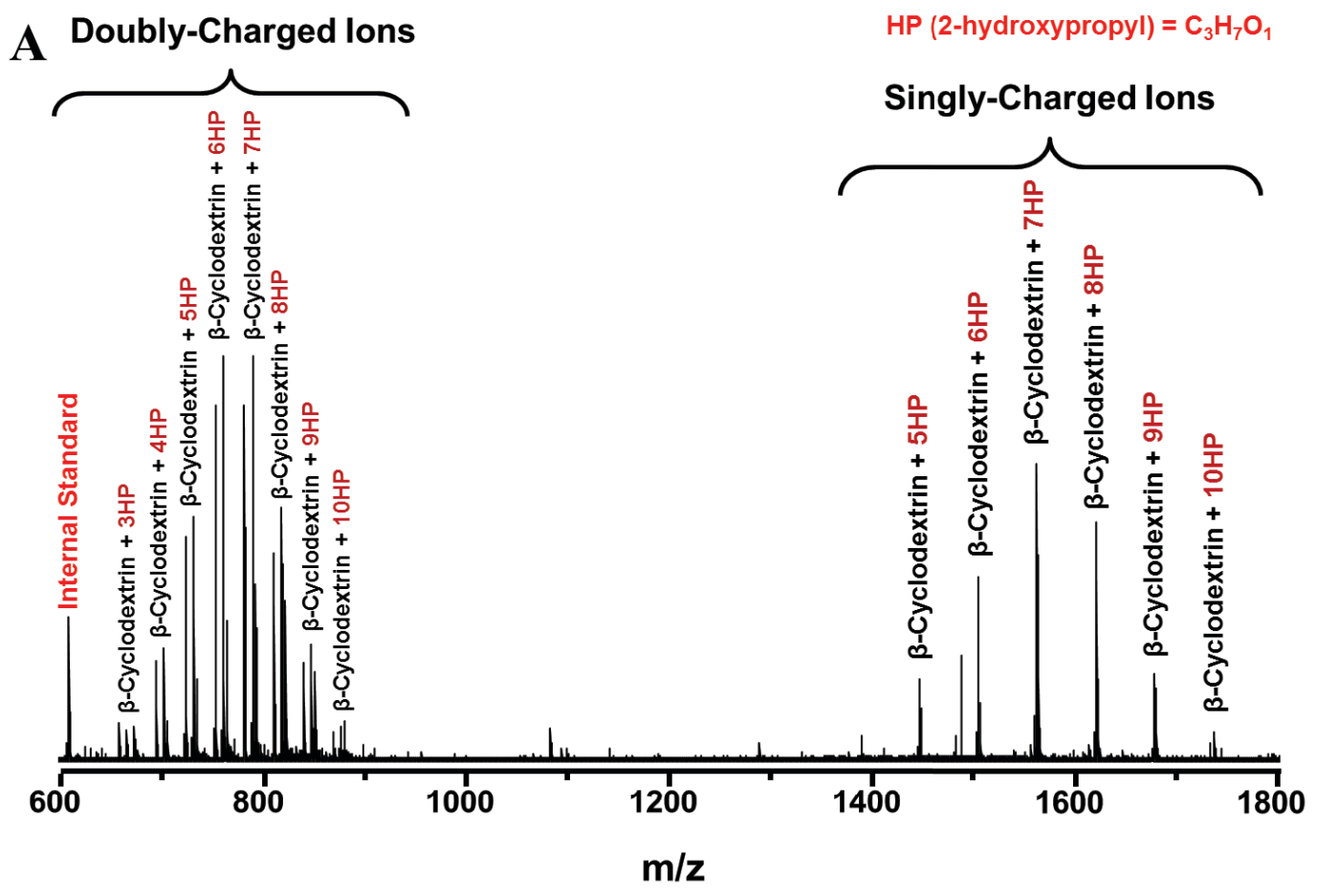

Fig. 3a.

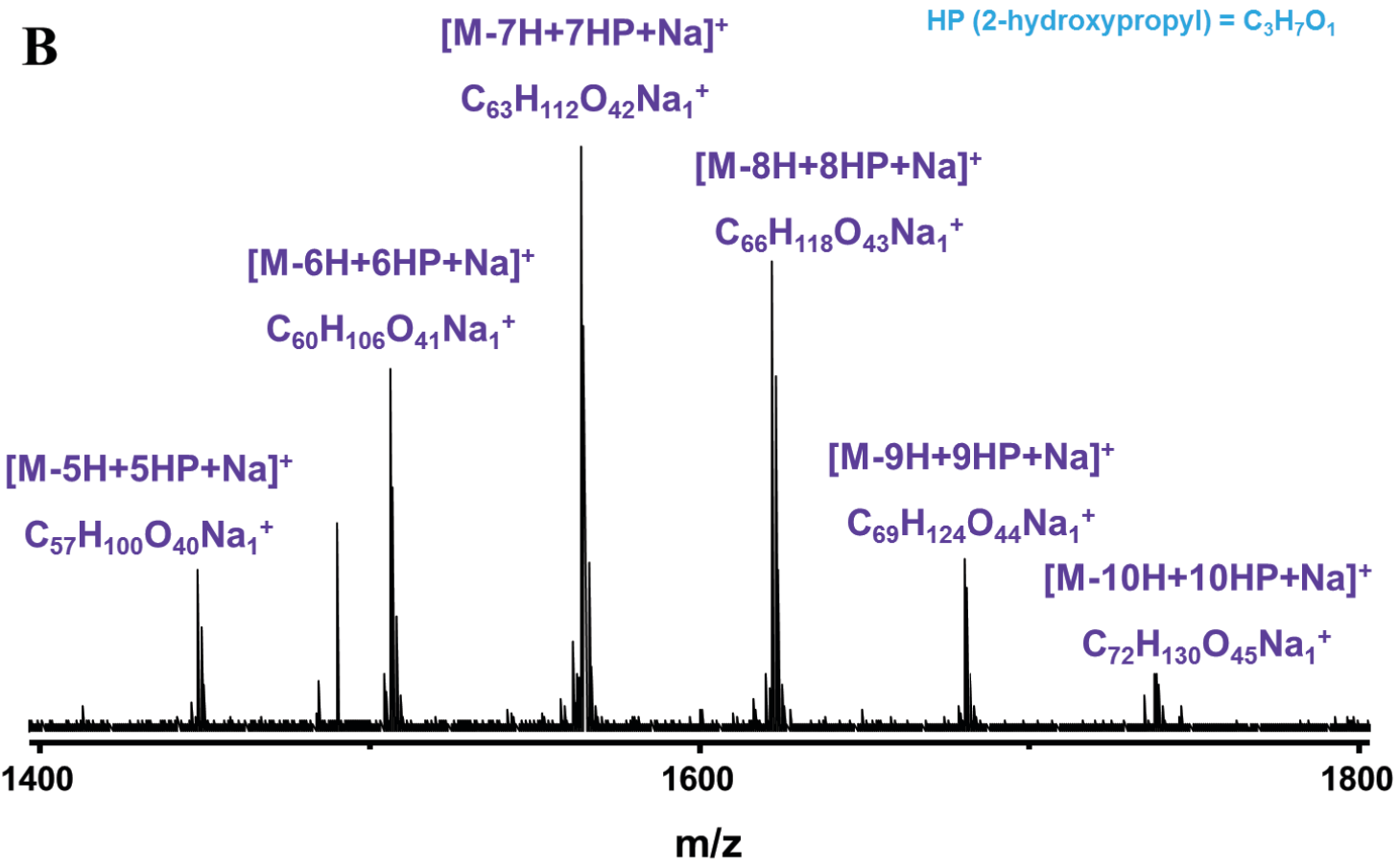

Fig. 3b. 


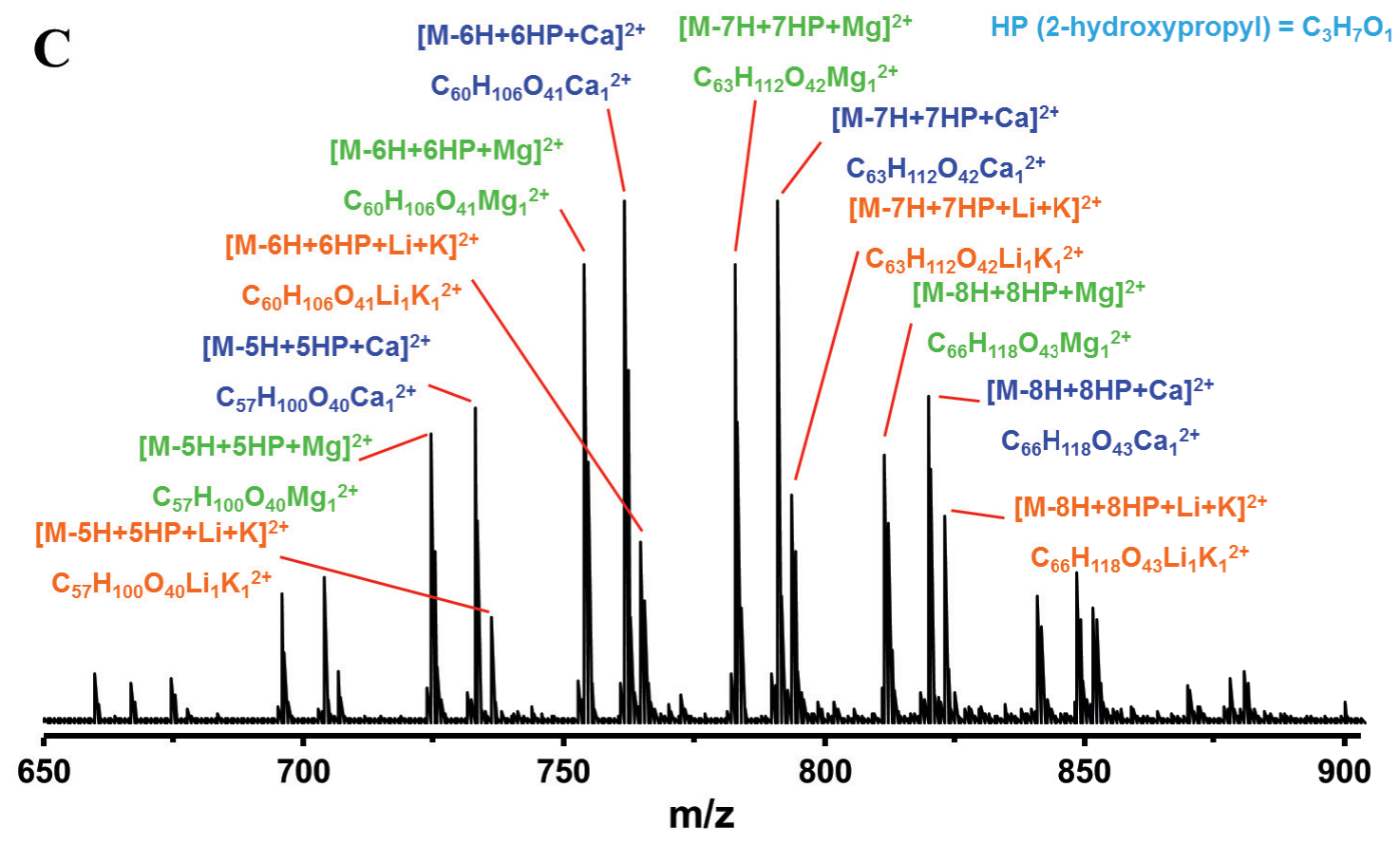

Fig. 3c. 

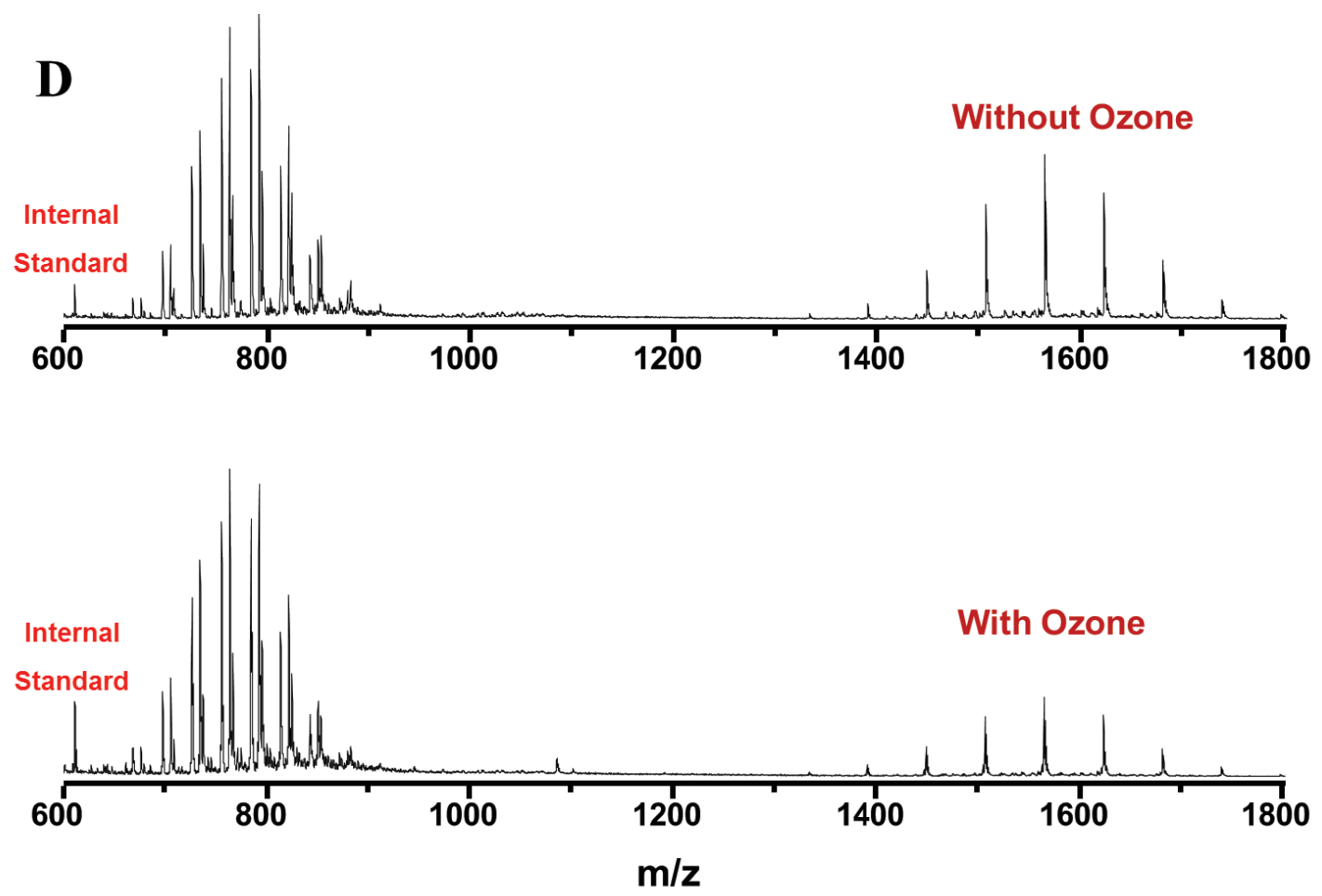

Fig. 3d.

Fig. 3. (A) Broadband ESI FT-ICR MS for $\operatorname{HP} \beta C D(250 \mathrm{mg} / \mathrm{L} ; 182 \mu \mathrm{M})$ in groundwater with $2 \mathrm{mg} / \mathrm{L}(41.7 \mu \mathrm{M})$ ozone. (B) FT-ICR MS (expanded from A) illustrating singlycharged ions (the observed sodium adducts $\left([\mathrm{M}+\mathrm{Na}]^{+}\right)$show serial addition of 2hydroxypropyl groups), and (C) doubly-charged ions. (D) Linear ion trap MS for HP $\beta C D$ showing transformation of $\mathrm{HP} \beta \mathrm{CD}$ (originally $250 \mathrm{mg} / \mathrm{L} ; 182 \mu \mathrm{M}$ ) upon exposure to 2 $\mathrm{mg} / \mathrm{L}(41.7 \mu \mathrm{M})$ ozone in groundwater by comparison of spectra with and without ozone exposure, peak heights are scaled to largest peak, and internal standard concentrations are identical. 


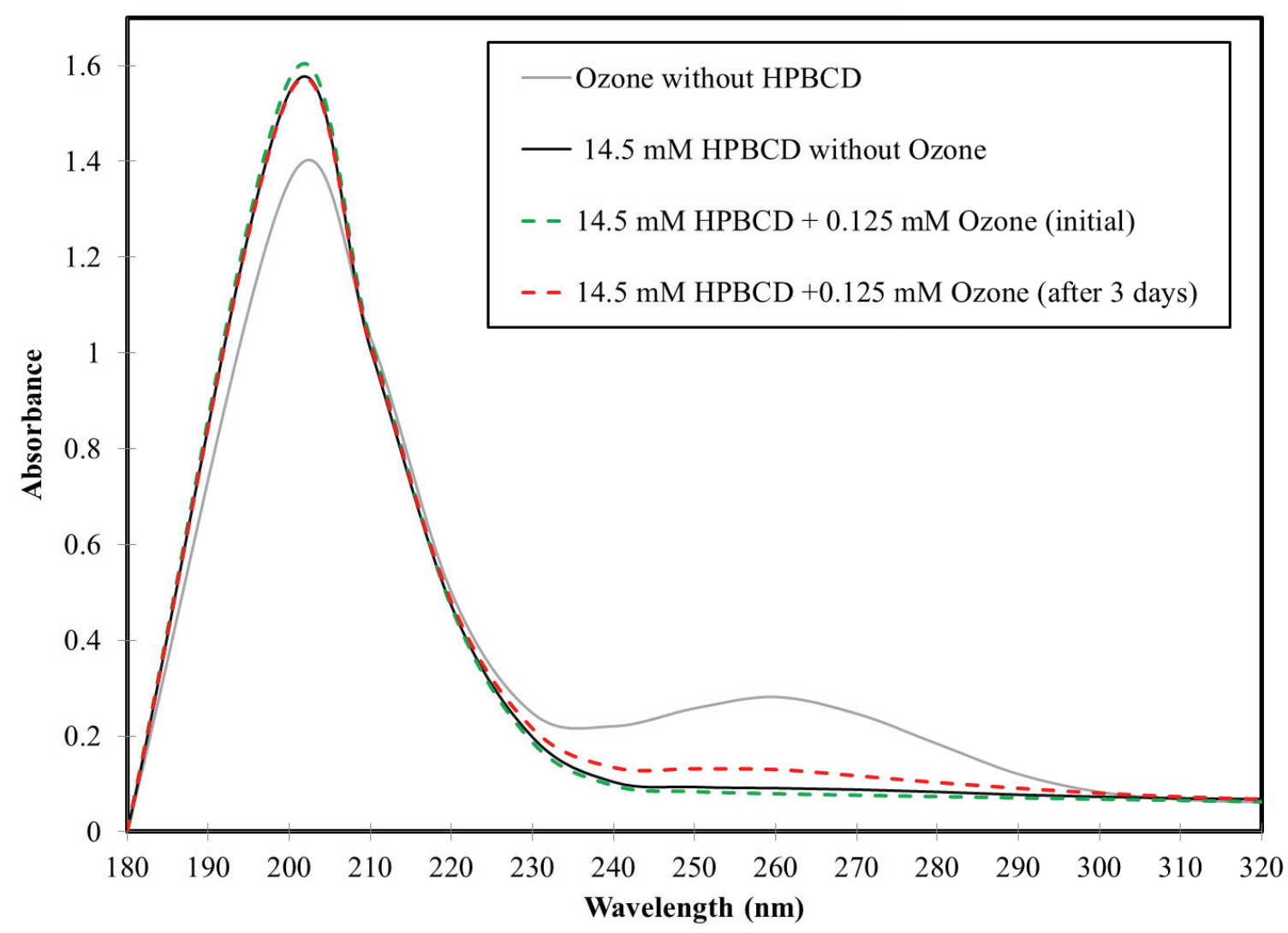

Fig. 4. Spectrophotometry confirmation of ozone complexation by HP $\beta C D$. HP $\beta C D$ adsorbs at $205 \mathrm{~nm}$, and absorbance increases at $205 \mathrm{~nm}$ with addition of ozone then decreases when ozone decays after 3 days. Ozone absorbance occurs at $205 \mathrm{~nm}$ and 260 nm. 

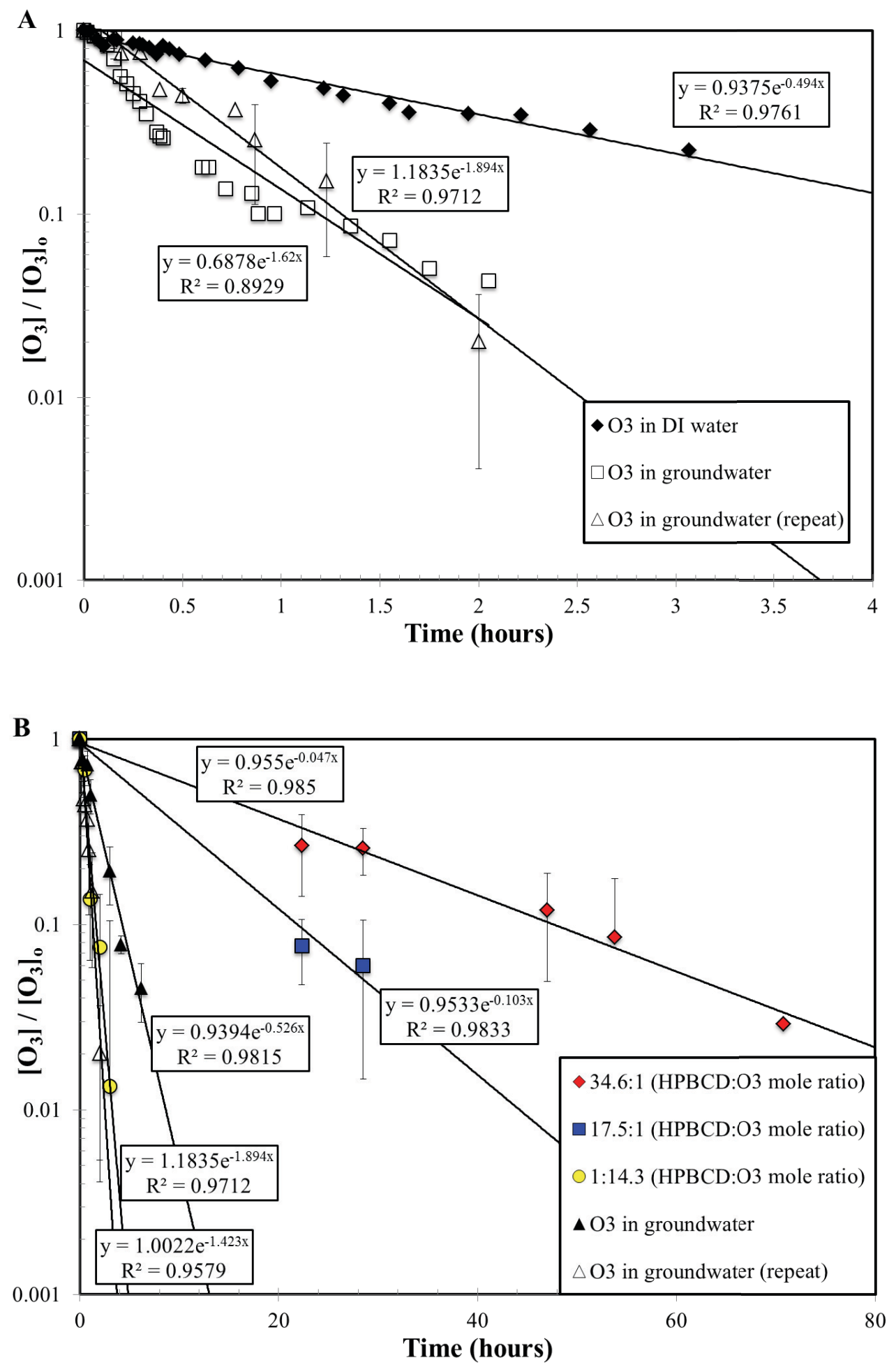

Fig. 5. (A) Ozone decay in DI and groundwater and (B) in groundwater containing varying $\mathrm{HP} \beta \mathrm{CD}: \mathrm{O}_{3}$ molar ratios. Error bars represent the $95 \%$ confidence interval for triplicates. Pseudo $1^{\text {st }}$ order kinetic analysis was used. 


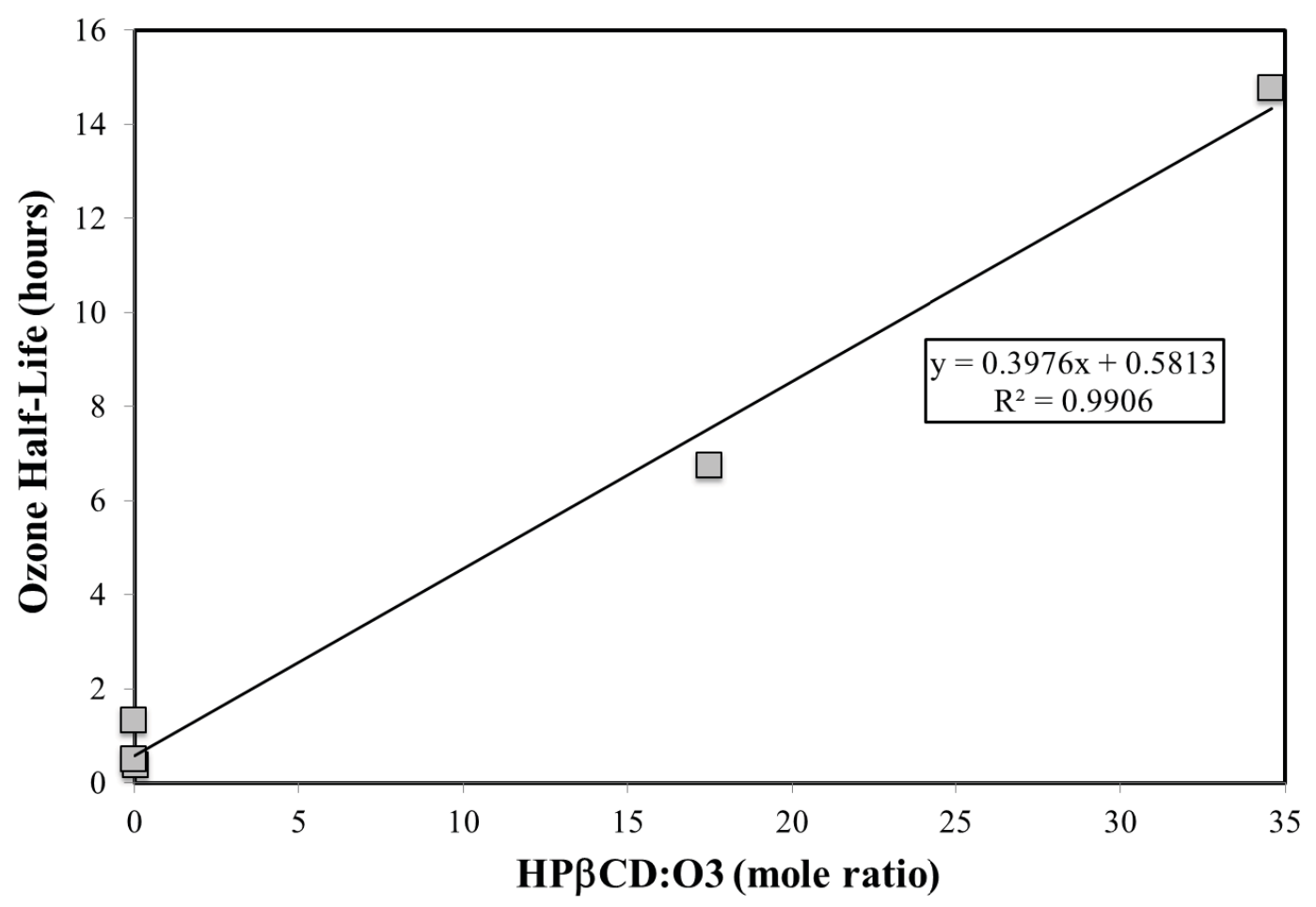

Fig. 6: Ozone half-life (ozone decay experiments; see Table 2) times plotted as a function of $\mathrm{HP} \beta \mathrm{CD}: \mathrm{O}_{3}$ molar ratio, and the line presents the linear regression analysis. 


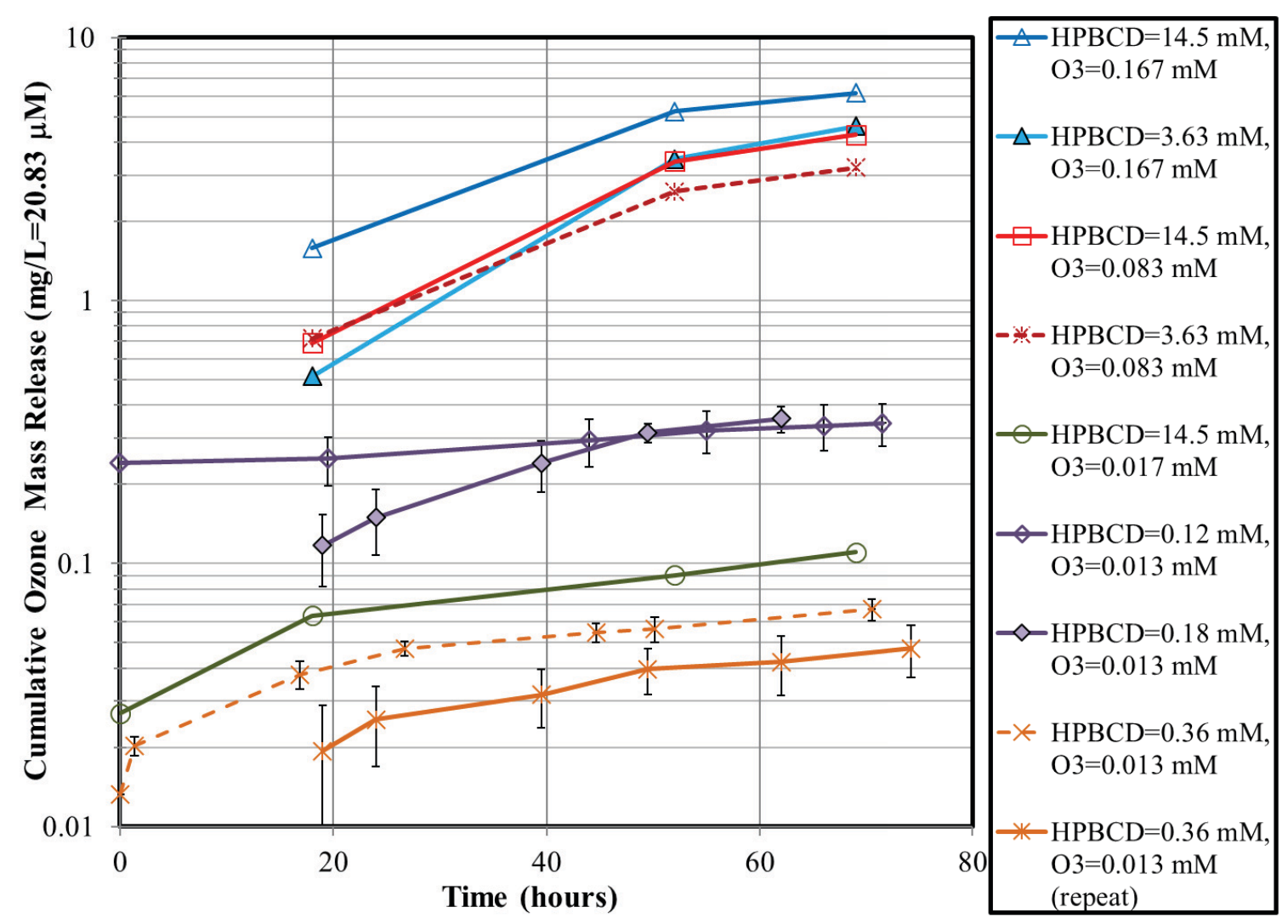

Fig. 7. Stabilized ozone cumulative concentration versus time with potassium indigo trisulfonate in $\mathrm{HP} \beta C D$ solution with various $\mathrm{HP} \beta C D$ to ozone ratios. Error bars (where present) represent the $95 \%$ confidence intervals. 